\title{
MEDIA DARING SEBAGAI SELF DIRECTED LEARNING MATERI PAI SD PADA MASA PANDEMI COVID-19
}

\author{
Misbahul Munir \\ Sekolah Tinggi Agama Islam (STAI) Ma'had Aly Al-Hikam Malang \\ misbah@staima-alhikam.ac.id \\ Triyo Suprayitno \\ Universitas Islam Negeri (UIN) Maulana Malik Ibrahim Malang \\ triyo@pai.uin-malang.ac.id
}

\begin{abstract}
:
The purpose of this research is to offer alternative media based on independent learning during the pandemic covid 19. The first objective is to explore information on online network-based media that is widely used in Indonesia as a support for learning; Second, to search a model of self-directed learning theory that has characteristics according to research needs; Third, to provide an overview of the alternative characteristics of online-based learning media offered. The data in this study were taken through google schoolar, semantic scholar, elsevier, researchgate, online seminars via youtube, zoom. The results of this study the most widely used media in Indonesia are Youtube, Facebook, WhatsApp, Zoom, Google Classroom. While the theory taken related to self directed learning according to Song and Hill's, The typology of youtube, facebook, whatsapp, zoom, and google classroom media is found to be opened, closed, open and closed combination for the public. All media have in common can share files in the form of video, word, pdf. Except youtube and zoom. The benefit of Youtube is the flexibility of time and content developed with audio visual, while zooming does not have the flexibility of time, learning can be presented interactively between teachers and students.
\end{abstract}

Kata Kunci: Online Media, Self Directed Learning, PAI 


\begin{abstract}
Abstrak
Tujuan dari penelitian ini untuk mewarkan alternatif media berbasis pembelajaran mandiri saat pancemi covid 19. Tujuan pertama untuk menggali infromasi media berbasis jaringan online yang banyak digunakan di Indonesia sebagai penunjang pembelajaran; Kedua, mencari model teori self directed learning yang memiliki karakteristik sesuai dengan kebutuhan penelitian; Ketiga, memberikan gambaran karakteristik alternatif media pembelajaran berbasis online yang ditawarkan. Data pada penelitian ini diambil melalui google schoolar, semanticscholar, elsevier, researchgate, seminar daring youtube, zoom. Hasil dari penelitian ini media yang paling balik dipakai di Indonesia Youtube, facebook, whatsapp, zoom, google classroom. Sedangkan teori yang diambil terkait self directed learning menurut Song dan Hill's, Adapun tipologi media youtube, facebook, whatsapp, zoom, dan google classroom didapatkan ada bersifat terbuka, tertutup, perbaduan terbuka dan tertutup untuk umum. Semua memedia memiliki kesamaan bisa berbagi file dalam bentuk video, word, pdf. Kecuali youtube dan zoom. Youtube kelebihan fleksibelitas waktu dan konten dikembangan dengan audio visual, sedangkan zoom tidak memiliki flesibilitas waktu, pembelajaran bisa tersajikan interaktif antara guru dengan siswa.
\end{abstract}

Kata Kunci: Media Online, Self Directed Learing, PAI

\title{
Pendahuluan
}

Virus Corona yang berasal dari Wuhan Provinsi Hubei China ini kini telah menjalar ke seluruh dunia. Bukan hanya korban jiwa akibat pandemic virus ini, namun juga menjalar ke berbagai sektor lain mulai dari politik, ekonomi, hingga pendidikan. Seperti diketahui bersama, virus corona akan mudah tersebar lewat cairan atau droplet, dan droplet tersebut sangat rawan tersebar apabila berada dalam situasi yang ramai, penuh sesak, dan berhimpitan. ${ }^{1}$

Penyebaran COVID-19 di Indonesia terkonfirmasi pada tanggal 2 Maret 2020 dengan jumlah penderita sebanyak 2 orang. ${ }^{2}$ Tanggal 8 Maret satu hari sebelum Menteri Pendidikan dan Kebudayaan atau dua hari sebelum Menteri kesehatan mengeluarkan maklumat surat edaran, dilaporkan terdapat 6 kasus pasien positif covid-

\footnotetext{
1 Kementerian Kesehatan, Surat Edaran Nomor HK.02.01/Menkes/199/2020 Tentang Komunikasi Penanganan Covid-19, 2020.

${ }^{2}$ Redaktur CNN Indonesia. "Jokowi Umumkan Dua WNI Positif Corona di Indonesia." CNN Indonesia, Maret 2, 2020.
} 
19 dengan jumlah total pasien dalam pengawasan sejumlah 23 orang. ${ }^{3}$ Sedangkan kondisi terakhir tanggal 1 April 2020, terkonfirmasi 1528 positif Covid-19 dengan jumlah pasien meninggal sebanyak 136 orang. ${ }^{4}$

Berdasarkan data diatas, aktivitas belajar mengajar sendiri khususnya yang konvensional, yakni proses pembelajaran yang mempertemukan pengajar dengan murid dalam satu ruang, memiliki kerentanan tinggi terhadap penyebaran virus covid-19. Karenanya aktivitas belajar mengajar menjadi sangat rentan apabila terus dilakukan di tengah pandemi hari ini. Kebijakan mengganti pertemuan aktivitas belajar mengajar adalah hal yang paling masuk akal untuk dilakukan, selain mencegah penyebaran juga menyelamatkan pendidik dan peserta didik dari terjangkiti virus. ${ }^{5}$

Kondisi ini menuntut peran guru untuk melakukan inovasi maupun modernisasi model pembelajaran dari konvesional pertemuan tatap muka yang mempertemukan guru dan siswa secara langsung dalam ruang kelas ke model berbasis teknologi dengan memanfaatkan jaringan online sebagai media, siswa belajar tanpa tatap muka dalam ruang kelas. ${ }^{6}$ Meskipun dalam praktiknya guru kurang siap dalam melakukan model pembelajaran sistem daring. Menurut Hague \& Payton tuntutan bagi pendidik bukan hanya transfer pengetahuan saja, tetapi perlu memiliki kemapuan tambahan untuk memfungsikan perangkat berbasis internet. ${ }^{7}$

Kemampuan inovasi yang dimiliki guru dalam merespon perubahan darurat seperti saat ini sangat terbatas, sebagaian besar kurang responsive untuk menghadapi perubahan maupun kondisi darurat seperti sekarang yang belum pernah diprediksi sebelumnya. Berdasarkan hasil penelitian tentang persepsi inovasi pendidik yang diterbitkan antara tahun 1999 dan 2015 diambil dari sampling Sembilan negara. Diperoleh data bahwa sebagian guru menganggap bahwa inovasi hanya sebatas

\footnotetext{
${ }^{3}$ Perwitasari, Nur Hidayah. "Update Corona 8 Maret: 59.965 Orang Sembuh dari COVID-19." tirto.id, 3 8, 2020.

4 Redaktur Kompas, 'Data Covid-19 Di Indonesia', Www.Kompas.Com, 31 March 2020 <https://www.kompas.com/covid-19>.

${ }^{5}$ Menteri Pendidikan dan Kebuayaan, Surat Edaran Nomor 3 Tahun 2020 Tentang Pencegahan COVID19 Pada Satuan Pendidikan, 2020.

${ }^{6}$ Lee, Ju-Sung, and Seok-Ju Chun. "Using Learning Management Systems for Self-directed Learning of Elementary School Students." Journal of The Korean Association of Information Education 23, no. 2 (2019): 1229-3245.

${ }^{7}$ Hague, Sarah Payton and Cassie. Digital Literacy across the Curriculum. Bristol: Futurelab, 2010.
} 
kebebasan menyampaikan pendapat didalam kelas. ${ }^{8}$ Pandangan tersebut mengartikan bahwa dalam pandangan guru inovasi belum pada kemampuan mengkolabarasikan pengajaran dengan mempergunakan teknologi.

Pada penelitian ini penulis ingin mengajak pembaca untuk mendiskusikan terkait model inovasi apa yang seharusnya dilakukan oleh pendidik ditengah kondisi darurat covid-19 seperti sekarang. Perta perlu kita ketahui bersama, bahwa mata pelajaran PAI bukan hanya transfer pengetahuan tapi syarat etika. Kedua kondisi kognitif peserta didik tergantung pada leveling usia, artinya perlu untuk memberikan alternative teknologi pengantar yang tepat.

Berdasarkan masalah yang terjabarkan diatas penulis akan mengulas pembahasan; Pertama, menggali data media dalam jaringan online yang banyak digunakan masyarakat;Kedua, Mencari konsep teoritis pembelajaran self directed learning; Ketiga, tawaran media pembelajaran berbasis dalam jaringan online untuk mata pelajaran PAI untuk menunjang pembelajaran pada saat system pemebalajaran mandiri dari rumah.

\section{Metode Penelitian}

Tujuan dari penelitian ini adalah untuk memberikan tawaran alternatif media pembelajaran berbasis sistem jaringan online. Maka cara yang digunakan dalam menggali informasi adalah mencari data, memilih sumber literatur, dan menyuseuaikan bahan yang menjadi kajian. Pertama, menggali informasi terkait data media yang banyak di gunakan di Indonesia. Penggalian data terkait media ini sangat penting dilakukan, karena media yang ditawarkan akan mempermudah pengguna dalam memanfaatkannya sebagai media pembelajaran. Kedua, menggali konsep teori terkait pembelajaran mandiri. Mencari satu konsep teori relevan dengan tawaran model media pembelajaran berbasis online, pengambilan keputusan teori diambil berdasarkan penilai perspektif peneliti terkait pengukuran relevansinya. Ketiga, menggali karakteristik media yang dipilih berbasarkan data penelitian pengguna terbanyak di Indonesia, kemudian memberikan gambaran terkait karakteristik dan fungsi penggunaan media. Literatur yang dikumpulkan berasal dari mesin pencarian online artikel ilmiah. Data

\footnotetext{
${ }^{8}$ Dianna R. Dekelaita-Mullet, Kristen. Lamb, and Todd. Kettler, 'Examining Teacher Perceptions of Creativity: A Systematic Review of the Literature', Thinking Skills and Creativity, 21 (2016), 9-30.
} 
diambil melalui portal publikasi ilmiah, google schoolar, semanticscholar, elsevier, researchgate, seminar daring youtube, zoom serta informasi dari media online serta data-data penunjang lainnya.

\section{Media Daring Penunjang Pembelajaran}

Model aplikasi berbasis dalam jaringan online memiliki beragam model pendukung, baik dalam bentuk web maupun aplikasi selular. Aplikasi tersebut bisa dikembangkan sebagai pendukung proses belajar mengajar jarak jauh, artinya tidak ada ruang pembatas bertemunya guru dan siswa dalam satu tempat. ${ }^{9}$

Pola guru mengajar saat ini sedang menghadapi kondisi yang berbeda dengan pola sebelum munculnya wabah covid19. Guru bisa menggunakan media internet sebagai sarana informasi dan komunikasi yang setiap hari berbagai pengetahuan baru terpublikasi dalam jaringan online, menuntut pendidik untuk menyesuaikan model pengajaran sesuai dengan perkembangannya. Karakteristik pembelajaran dalam jaringan online menurut Friedman yang diringkas menjadi 5 K: komunikasi, kolaborasi, komunitas, kreatifitas, dan konvergensi, sebagaimana peneliti analisis pada tabel. 1 dibawah ini dengan menggunakan pendekat Fredman. ${ }^{10}$

Tabel 1. Karakteristik Media Daring Friedman

\begin{tabular}{ll}
\hline Karakteristik & \multicolumn{2}{c}{ Penjelasan } \\
\hline Komunikasi & Komunikasi dalam daring memungkinkan proses \\
& pembelajaran tanpa tatap muka secara langsung, \\
& pertemuan guru dengan siswa bisa melalui bantuan \\
& media yang terhubung jaringan internet, sehingga \\
& proses pembelajaran tidak harus bertatap muka secara \\
& langsung di dalam kelas. \\
\hline Kolaborasi & Pembelajaran berbasis daring bisa dirancang oleh guru \\
& secara kolaborasi. Misalnya mengoptimalkan sarana
\end{tabular}

\footnotetext{
9 Davis, Charles H.F., Regina Deil-Amen, Cecilia Rios-Aguilar, and Manuel Sacramento Gonzalez Canche. Social Media in Higher Education: A literature review and research directions. The Center for the Study of Higher Education at The University of Arizona and Claremont Graduate University, 2012

${ }^{10}$ Friedman, Linda Weiser, and Hershey H. Friedman. "Using Social Media Technologies to Enhance Online Learning." Journal of education online 10, no. 1 (2013), 22.
} 
media, berbagi informasi untuk pengembangan strategi, model, membagi informasi pengetahuan bagi antar guru, dan menciptakan media pembelajaran yang bisa dipakai bersama.

\begin{tabular}{ll}
\hline Komunitas & Komunitas pada model pembelajaran berbasis jaringan \\
& online bisa berupa grub komunikasi antar guru, grub \\
& kelas tempat berbagi pengetahuan seputar materi yang \\
& dipelajari. Media dalam membuat komunitas online \\
& misalnya grub whatsapp, telegram, facebook, maupun \\
& media social lainnya yang pendukung share materi dan \\
& memiliki karakterik didalamnya anggota komunitas \\
& kelas masuk didalamnya. \\
& Media pembelajaran memberikan kemudahan untuk \\
& saling berbagi informasi dalam pengembangan \\
& kreatifitas maupun inovasi bagi guru dalam \\
& meningkatkan kapasitas diri. Dengan hadirnya \\
& teknologi guru tidak harus mendatangai ahli untuk \\
& mendapatkan wawasan pengembangan media, melaui \\
& media online guru bisa mendapat akses informasi tanpa \\
& batas. Misalnya video tutorial terkait pengembangan \\
& aplikasi pembelajaran yang tersedia di youtube. \\
& Manfaat bagi guru, guru bisa memiliki kemampuan \\
& mengembangkan perangkat media, sedangkan bagi \\
& siswa memungkinkan memperoleh pengetahuan lebih \\
& dari pada yang seharusnya didapatkan dalam ruang \\
& kelas.
\end{tabular}

Konvergensi Kovergensi dalam peruban model pembelajaran online, telah memberikan peruban bagi dua pendidikan. Peran guru maupun siswa yang mengharuskan bertemu dalam satu tempat dan waktu. Saat ini memungkin alternatif perubahan dari bertemunya guru dengan 
murid secara langsung, baik waktu dan tempat.

Adaptasi adalah kunci untuk bertahan hidup di era

Internet.

Pembelajaran dengan sistem dalam jaringan online memiliki kelebihan dalam hal fleksibilitas, artinya proses pembelajaran bisa dilakukan dengan mengkolaborasikan pertemuan online dan pertemuan tatap muka secara langsung. ${ }^{11}$ Penerapan pembelajaran dalam jaringan online pada masa pandemic covid-19 seperti yang terjadi saat ini penting dilakukan. Tetapi perlu menentukan media berbasis online apa yang paling banyak dipakai serta memiliki konten yang bisa mendukung proses pembelajaran.

Sebagai alternatif pendukung proses pembelajaran pada saat masa pandemic covid-19. Berdasarkan data penelitian, ${ }^{12}$ didapatkan 3 media social posisi teratas yang paling banyak digunakan di Indonesia berdasarkan prosentase pengguna. Diantaranya youtube menempati posisi pertama sebesar (82\%), whatsapp sebesar (84\%), facebook sebesar (82\%). Selain media pendukung pembelajaran dalam jaringan online tersebut, zoom dan google classroom mengalami peningkatan signifikan unduhan oleh pengguna ios mapun android pada bulan Maret hingga April 2020. ${ }^{13}$

\section{Konsep Self Directed Learning}

Pembelajaran dengan konsep Self Directed Learning ialah model pembelajaran dengan memberikan ruang kepada invidu untuk mendapatkan pengajaran di luar lingkung pendidikan formal dengan control secara mandiri. Pembelajaran model mandiri memberi ruang kepada individu untuk menggali potensinya dengan bantuan sumberdaya yang dimiliki, baik dalam menetapkan tujuan, maupun strategi untuk mencapai prestasinya belajarnya. ${ }^{14}$

\footnotetext{
${ }^{11}$ Jaschik, Scott. "The evidence on online education." Inside Higher Education, Juni 29, 2009.

${ }^{12}$ Hootsuite; We are Social. 10 Media Sosial yang Paling Sering Digunakan di Indonesia. Hootsuite (We are Social), 2019.

13 Riadi, Yuni. Karena Covid-19, Google Classroom Sudah Diunduh 50 Juta. Maret 30, 2020. https://selular.id/2020/03/karena-covid-19-google-classroom-sudah-diunduh-50-juta/. Lihat Dialektika. Zoom Capai 131 Juta Download, Ini 10 Aplikasi Paling Banyak Diunduh Selama April. May 11, 2020. https://teknologi.id/aplikasi/zoom-capai-131-juta-download-ini-10-aplikasi-paling-banyak-diunduhselama-april.

${ }^{14}$ ADAGIDELİ, Fahretdin Hasan, Seda SARAÇ, and Engin ADER. "Assessing Preschool Teachers' Practices to Promote Self-Regulated Learning." International Electronic Journal of Elementary Education 7, no. 3 (2015).
} 
Percepatan berubahan di era globalisasi menuntut individu untuk memiliki kemampuan beragam, artinya disamping memiliki kompetensi sesuai minat juga perlu menambah kemampuan dalam mengoperasikan teknologi, ini penting dilakukan, karena tuntutan globalisasi sangat cepat berubah. Sehingga invidu perlu untuk memompa beragam kompetensi yan bisa digali tanpa batas ruang dan waktu. Bejalar dengan system mandiri mampu menggali kreatifitasnya. ${ }^{15}$

Sebagai tawaran adalah pembelajaran dalam jaringan online dengan pendekatan self directed learning dipilih sebagai alternatif pembelajaran di tengah kondisi darurat pandemic covid 19 saat ini. Garrison mengatakan untuk membangun komunitas belajar mandiri sangat bergantung pada kondisi kecerdasan serta kemauan individu untuk menggali berbagai informasi yang telah tersedia dalam dunia virtual internet. ${ }^{16}$

Konsep self directed learning yang diambil oleh peneliti adalah menurut Song dan Hill's, pemilihan didasarkan pada gagasan yang ditawarkan memiliki karakteristik dipengaruhi oleh dua faktor; pertama, personal atibutes; kedua, processes. Dua factor tersebut digunakan untuk memahami lingkungan virtual dalam jaringan online mampu memberikan pengaruh pada peserta didik untuk belajar secara mandiri, sebagai konsep terjabarkan pada gambar. 1 dibawah ini.

\section{Gambar. 1 Konsep Self Directed Learning Song dan Hill's} Self Diredted Learning Context

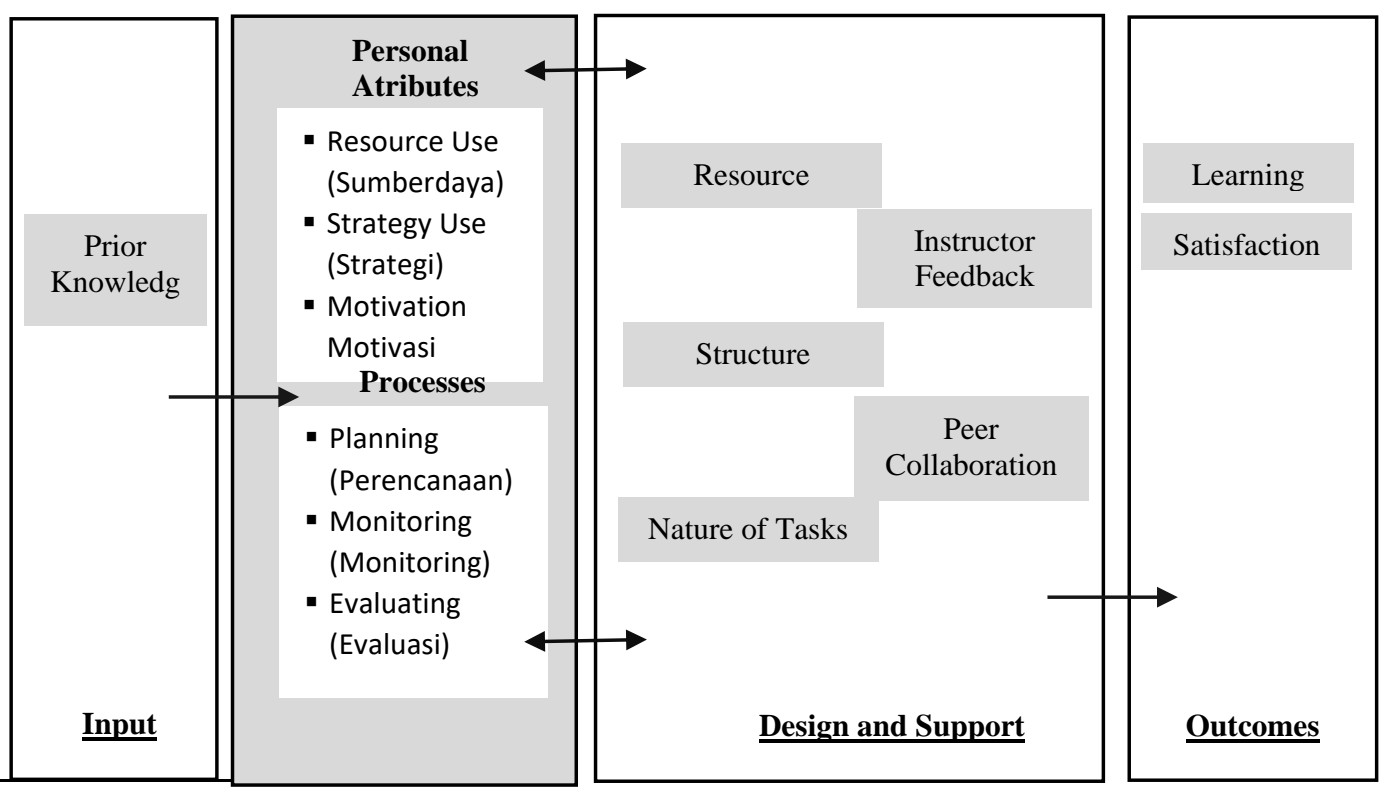

15 Lee, Kyunghwa. What should be the innovative teaching and learning methods for future talent? International Future Society \& KERIS (Korea Education \& Research Information Service (Eds.). Paju: Kwnagmoongak, 2017.

${ }^{16}$ Garrison, Donn Randy. E-learning in the 21st century: A framework for research and practice. New York: Routledge, 2017. 


\section{Resource Use}

Sumber daya yang dimaksud dalam konsep Self Directed Learning tidak terbatas pada sumberdaya manusia dan sumberdaya informasi, namun bukan berarti pembelajaran tidak memiliki capaian kurikulum yang jelas. ${ }^{17}$ Pada sumberdaya manusia, pembelajaran dirancang mandiri, meskipun tanpa hadirnya guru. Posisi guru sebagai perancang konten pembelajaran, kemudian menyampaikan dalam sistem dalam jaringan online. Siswa bisa mengakses pengetahuan banyak pengetahuan, tidak terbatas satu sumber saja.

\section{Strategi Use}

Pemilihan strategi pembelajaran yang tepat dalam sistem pembelajaran Self Directed Learning sangat penting dilakukan. Pembelajaran model tanpa tatap muka secara langsung guru dengan siswa melalui perangkat terkadang memunculkan salah penafsiran dari materi yang disampaikan oleh guru dengan materi yang ditangkap oleh siswa. Oleh karenanya strategi yang perlu dirancang berkaitan dengan ekspresi wajah, intonasi suara, maupun bahasa tulis yang bisa memudahkan siswa untuk menangkap informasi yang disampaikan oleh guru melalui sistem online. ${ }^{18}$

\section{Motivation}

Menumbuhkan motivasi pada Self Directed Learning berbeda polanya dengan sistem pembelajaran tatap muka secara langsung mempertemukan guru dengan siswa didalam kelas. Pembelajaran mandiri dengan sistem online memisahkan peran guru dalam pengawasan terhadap siswa secara langsung. ${ }^{19}$ Siswa yang terlibat dalam pembelajaran secara online bisa leluasa melakukan apapun tanpa fokus terhadap materi yang disampaikan oleh guru, karena model online kurang

\footnotetext{
17 Hill, Janette R., and Michael J. Hannafin. "Teaching and learning in digital environments: The resurgence of resource-based learning." Educational Technology Research and Development 49, no. 3 (2001): 37-52.

18 Petrides, Lisa. "Web-based technologies for distributed (or distance) learning: Creating learningcentered educational experiences in the higher education classroom." International Journal of Instructional Media 29, no. 1 (2002): 69-77.

${ }^{19}$ Biesenbach-Lucas, Sigrun. "Asynchronous discussion groups in teacher training classes: Perceptions of native and non-native students." Journal of Asynchronous Learning Network 7, no. 3 (2003): 24-46.
} 
memberikan interaksi antara guru dengan siswa, tetapi secara realita dilapangan bisa saja siswa melakukan kegiatan lain melalui perangkat online. ${ }^{20}$

4. Planning, monitoring, evaluating

Perencanaan, monitoring, dan evaluasi dalam rancangan pembelajaran Self Directed Learning perlu dilakukan agar pembelajaran berjalan sesuai dengan tujuan pembelajaran. Mempersiapkan pembelajaran dengan sistem dalam jaringan online tentunya berbeda dengan model pembelajaran tatap muka secara langsung dalam kelas. $^{21}$ Tahap perencanaan pembelajaran dalam jaringan online yaitu dengan pempersiapan aplikasi penunjang yang mudah dipergunakan baik oleh guru maupun siswa. Kemudian pada tahap monitoring dilakukan dengan memberikan umpan balik dari pembelajaran sistem online, bisa dilakukan dengan perangkat aplikasi chat maupun media sosial. Pada tahap evaluasi memiliki hanya pada mengukur kompetensi yang sudah diperoleh anak ketika pembelajaran, guru tidak memiliki akses untuk mengamati bagaimana anak bisa menggunakan kompetensinya dalam kehidupan.

\section{Tawaran Media Daring Sebagai Self Directed Learning Materi PAI SD}

\section{Karakteristik Kognisi Siswa Sekolah Dasar}

Karakteristik kognisi bergantung pada kesiapan mental dan rentang usia peserta didik. Adapun keseiapan mental yang harus dimiliki peserta didik yang berkaitan dengan keseimbangan antara sikap, pengetahuan dan keterampilan sangat diperlukan dalam proses pengajaran. Untuk itu kiranya perlu dilakukan kajian analisa ketepatan penyampaian pengajaran yang berbentuk sikap melalui pemberian contoh, pengetahuan melalui transfer informasi, skill yang dibentuk dari kreatifitas mengolah pengetahuan. Sebagaimana pada gambar 1 dibawah ini mgengenai katakteristik soft skill dan hard skill siswa sekolah dasar dilihat dari teori Marzano dan Bruner.

\footnotetext{
20 LPM Idea. [In Depth] Kuliah Online Mahasiswa Korban Corona. April 28, 2020. https://www.ideapers.com/2020/04/in-depth-kuliah-online-mahasiswa-korban-corona.html.

21 Song, Liyan, and Janette R. Hill. "A conceptual model for understanding self-directed learning in online environments." Journal of Interactive Online Learning 6, no. 1 (2007): 27-42.
} 
Gambar. 1

Soft Skills dan Hard Skills Marzano dan Bruner

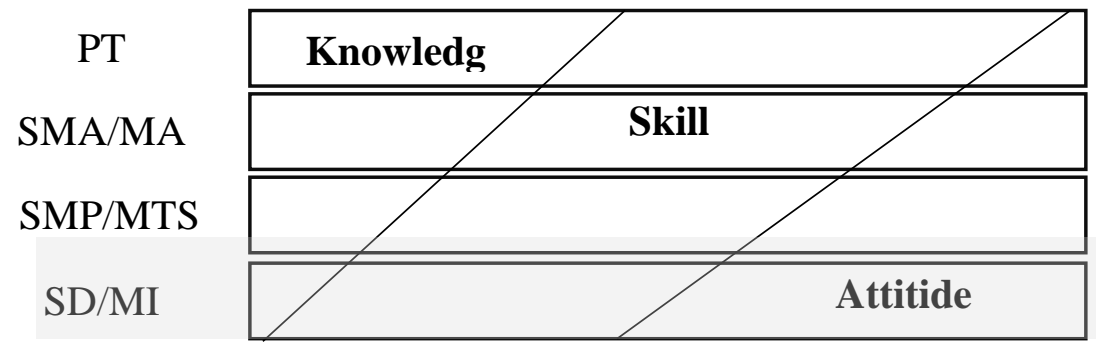

Berdasarkan gambar 1 diatas diadopsi dari pemikirannya Marzano $^{22}$ dan Bruner memberikan ruang kesimbangan pada pengembangan soft skill dan hard skill tidak terlepas dari kematangan secara kognisi serta tingkatan jenjang pendidikan. Peserta didik yang berada di jenjang paling dasar, porsi pengajaran ditekankan pada pemodelan karakter melalui interaksi dengan lingkungannya. Peserta didik ditingkat dasar yang memiliki rentang usia 7-12 tahun memiliki kecenderungan untuk diarahkan kepada sesuatu yang baik atau yang buruk. ${ }^{23}$ Pendidikan pada tingkat dasar muatan pengajarannya lebih pada penekanan pembentukan sikap harus lebih diutamakan, tahap selanjutnya pada porsi keterampilan dan pengetahuan.

Tantangan bagi Pendidikan Islam saat ini, selain dihadapkan pada desain pengajaran untuk membentuk luaran memiliki cara pandang siap terhadap revolusi industri 4.0. Disisi lain tuntutan sesuai dengan tujuan Pendidikan Islam untuk menghasilkan luaran Pendidikan yang ideal taqarrub ila Allah, adapun sasaran utama sebagai manusia ideal dalam kehidupan dunia dan memiliki spirit untuk mempersiapkan kehidupan akhirat. Menurut Al Ghazali ada dua kunci utama dalam Pendidikan Islam. Pertama pada penetapan kurikulum yang tepat seuai dengan tingkatan kematangan, kedua metode pembinaan akhlak yang tepat. ${ }^{24}$

Pemetaan pada rancangan model muatan materi yang harus diberikan serta ketepatan metode pembinaan akhlak yang tepat perlu dirancang dengan baik oleh pendidik. Pendidikan Islam tidak lain adalah bagian dari proses penyiapan

\footnotetext{
${ }^{22}$ Marzano, Robert J. An Evaluation of the Mc Rel Thinking Skills Program. Colorado: Mid-continent Regional Educational Laboratory, 1986.

23 Al-Ghazali. MUTIARA IHYA ULUMUDDIN. Bandung: Mizan, 2008.

${ }^{24}$ Sulaiman, Fathiyah Hasan. Konsep Pendidikam Al Ghazali. Jakarta: Perhimpunan Pengembangan Pesantren dan Masyarakat (P3M), 1990.
} 
geranerasi unggul yang berkepribadian terpuji. ${ }^{25}$ Dibawah ini model pengajaran yang berisi muatan pengetahuan maupun pembinaan akhlak menurut al-Ghazali.

Tabel. 1

\section{Model Pengajaran Pendidikan Islam Al Ghazali}

\begin{tabular}{ll}
\hline Tingkat Usia & \multicolumn{1}{c}{ Model Pengajaran } \\
\hline At-Tamyiz (Usia 7 - 12 Tahun) & $\begin{array}{l}\text { Pemahaman (Penanaman keimanan, akhlak, } \\
\text { social, jasmani. } \\
\text { Pengajaran } \\
\text { Cerita }\end{array}$ \\
\hline Berdasarkan tabel diatas peserta didik mulai dari Pendidikan dasar dibagi \\
menjadi tiga tingkatan, tamyiz usia $7-11$ tahun. ${ }^{26}$ Pada level usia 7-11 penekanan \\
pengajarannya adalah pada pemahaman belajar terbimbing, ketika masuk usia 12- \\
18 pengenalan terhadap syara', moralitas berdasarkan sumber wahyu mulai \\
diperkenalkan, ketika masuk pada usia 18 tahun keatas tanggung jawab hukum \\
baik secara agama maupun negara sudah mulai dibebankan, pada usia ini peserta \\
didik sudah mulai mempunyai kemampuan analitik, sehingga pola pengajaran bisa \\
secara mandiri.
\end{tabular}

2. Materi Pendidikan Islam

Pendidikan agama Islam merupakan mata pelajaran untuk membentuk peserta didik baik secara sikap, yakni memliki sikap bertaqwa kepada Allah dan memiliki akhlak secara social dalam wujud kepribadian muslim ideal. ${ }^{27}$

Citra muslim ideal bukan berarti ditujukan pada persoalan akhirat saja. Tapi Pendidikan Islam adalah sebagai nilai untuk membentuk manusia secara positif, dan mampu memiliki peran dalam peradaban dunia. ${ }^{28}$ Ada beberapa perbedaan menonjol pada penekakan model Pendidikan Islam dengan model Pendidikan barat, sebagaimana tabel dibawah ini. ${ }^{29}$

\footnotetext{
${ }^{25}$ Langgulung, Hasan. Beberapa Pemikiran tentang Pendidikan Islam. Bandung: al-Ma'arif, 1995.

${ }^{26}$ Zainuddin. Seluk Beluk Pendidikan dari Al-Ghazali. Jakarta: Bumi Aksara, 1991.

${ }^{27}$ Syed Muhammad Al-Naquib al-Attas, Aims and Objectives of Islamic Education (Jeddah: King Abdul Aziz, 1979).

${ }^{28}$ Rahman, Fazlur. " Islam dan Modernitas: tentang Transformasi Intelektual." By A. Mohammad, 102. Bandung: Pustaka, 2005.

${ }^{29}$ Muhaimin, Model Kurikulum Dan Pembelajaran Dalam Pendidikan Islam Kontemporer (Malang: UIN Maliki Press, 2015).
} 
Tabel. 2

Perbedaan Model Pendidikan Islam dengan Barat

\begin{tabular}{ll}
\hline \multicolumn{1}{c}{ Pendidikan Islam } & \multicolumn{1}{c}{ Pendidikan Barat } \\
\hline Sumber wahyu (Al Quran dan Hadis) & Rasio dan Pakar \\
\hline Mengakui adanya alam gaib (tidak bias & Berhubungan dengan positivism \\
dicapai dengan indera) & \\
\hline Pendidikan dan pembelajaran ada & Tidak ada hubungan dengan Tuhan, \\
hubungannya dengan ibadah & nilai tertinggi adalah untuk \\
& kepentingan moral dan social \\
\hline Mengakui adanya kehidupan setelah mati & Pendidikan untuk kekinian \\
\hline Konsep Pendidikan dikaitkan dengan & Sama sekali tidak dikaitkan \\
pahala dan dosa & \\
\hline Meyakini bahwa terdapat hak-hak Allah & Keyakinan hak terhadap Tuhan sama \\
dan hak-hakmakhluk lainnya pada setiap & sekali tidak disinggung \\
manusia & \\
\hline Ilmu ada yang gaib & Ilmu adalah yang positif dan konkrit \\
\hline
\end{tabular}

\section{Tawaran Media Pembelajaran Berbasis Daring}

Media pembelajaran dengan sistem dalam jaringan online memberikan tekanan pada media sebagai pemberi informasi utama dalam pembelajaran. Posisi guru adalah sebagai fasilitator dalam menyiapkan bahan materi pembelajaran, memilih ketepatan media berdasarkan kebutuhan dan fungsi yang tepat sesuai dengan karakteristik materi dan tingkatan kognisi peserta siswa. Penjelasan mengenai tawaran media pembelajaran berbasis sistem dalam jaring terdapat pada tabel. 3 dibawah ini. 
Tabel. 3

Tipologi Media Pembalajaran Berbasis Dalam Jaringan Online

\begin{tabular}{|c|c|c|}
\hline $\begin{array}{c}\text { Media } \\
\text { Pembelajaran }\end{array}$ & Tipe Media & Fungsi \\
\hline Youtube & $\begin{array}{c}\text { Video } \\
\text { Conrefence }\end{array}$ & $\begin{array}{l}\text { - Sebagai media penyampai materi } \\
\text { pembelajaran berbentuk video } \\
\text { - Bisa dilakukan tanpa siaran langsung, } \\
\text { sehingga dalam hal waktu lebih fleksibel } \\
\text { - Terbuka untuk umum, tidak terkunci untuk } \\
\text { publik }\end{array}$ \\
\hline Facebook & $\begin{array}{l}\text { The Chat } \\
\text { Share link } \\
\text { chat }\end{array}$ & $\begin{array}{l}\text { - Memanfaatkan grub sebagai ruang kelas dan } \\
\text { berbagi video, file, mapun tanya jawab } \\
\text { dalam bentuk text chat. } \\
\text { - Salurannya bisa dibatasi khusus untuk } \\
\text { anggota kelas maupun bisa diatur untuk } \\
\text { umum didalam grubnya }\end{array}$ \\
\hline Whatsapp & $\begin{array}{c}\text { Text chat } \\
\text { Share video } \\
\text { dan share } \\
\text { file }\end{array}$ & $\begin{array}{l}\text { - Memanfaatkan grub wa sebagai ruang } \\
\text { belajar, berbagi video maupun bahan belajar } \\
\text { dalam bentuk share file } \\
\text { - Grub terbatas hanya untuk anggota kelas, } \\
\text { admin berhak mengatur siapa yang berhak } \\
\text { ada didalam kelas }\end{array}$ \\
\hline Zoom & $\begin{array}{c}\text { Live } \\
\text { Conrefence } \\
\text { Discussion } \\
\text { Forum }\end{array}$ & $\begin{array}{l}\text { - Anggota yang bisa bergabung dalam kelas } \\
\text { zoom bisa dibatasi hanya untuk siswa yang } \\
\text { sudah mendapatkan pasword dan link } \\
\text { - Penampilan secara live sehingga kurang } \\
\text { fleksibel, siswa wajib hadir sesuai waktu } \\
\text { yang disepakati } \\
\text { - Tidak bisa bertukar file maupun video } \\
\text { - Keunggunalannya pembelajaran bisa } \\
\text { dilakukan secara interaktif seperti }\end{array}$ \\
\hline
\end{tabular}




\begin{tabular}{|c|c|c|}
\hline & & $\begin{array}{l}\text { pembelajaran tatap muka dikelas, karena } \\
\text { dilakuakan secara live. }\end{array}$ \\
\hline $\begin{array}{l}\text { Google } \\
\text { Classroom }\end{array}$ & $\begin{array}{c}\text { Text chat } \\
\text { Share video, } \\
\text { file }\end{array}$ & $\begin{array}{l}\text { - Memanfaatkan grub wa sebagai ruang } \\
\text { belajar, berbagi video maupun bahan belajar } \\
\text { dalam bentuk share file } \\
\text { - Grub terbatas hanya untuk anggota kelas, } \\
\text { admin berhak mengatur siapa yang berhak } \\
\text { ada didalam kelas } \\
\text { - Konten disajikan secara lengkap dan bisa } \\
\text { terhubung dengan konten aplikasi google } \\
\text { lain. }\end{array}$ \\
\hline
\end{tabular}

\section{Penutup}

Temuan pertama, berdasarkan hasil pencarian data terkait media berbasis online yang paling banyak digunakan di Indonesia diperoleh Youtube paling banyak digunakan, whatsapp posisi kedua, facebook ketiga. Dua media online tambahan lainnya zoom dan google classroom. Data yang diperoleh ini sebagai dasar tawaran media yang bisa digunakan sebagai pembelajaran mandiri tanpa tatap muka.

Temuan kedua, pembelajaran berbasis self directed learning dapat berjalan dengan baik jika memperhatikan tiga pokok dasar. Pertama, perlunya kesiapan sumberdaya manusia maupun sumberdaya alat yang bisa mendukung pembelajaran online, sumberdaya tersebut perangkat internet, komputer,laptop HP. Kedua, strategi pengelolan konten pembelajaran perlu dirancang menarik. Ketiga, perlunya merancang konten pembelajaran yang memnungkinkan interaksi antara guru dengan siswa, dengan adanya interaksi antara guru dengan siswa, bisa memberikan ruang kepada guru untuk memotivasi siwa belajar.

Temuan ketiga, berdasarkan pemilihan media youtube, whatsapp, facebook, zoom, google classrom. Diperoleh gambaran karakteristik dari masing-masing media yang mempunyai keunggulan dan kekurangan. Karakteristik yang ditemukan antara lain, berbasis video yang mempunyai fleksibilitas waktu, video converence langsung, terbuka untuk umum, terkunci hanya untuk anggota kelas, didukung ruang share video, 
FIKROTUNA; Jurnal Pendidikan dan Manajemen Islam Volume. 11, Nomor. 02, Juli 2020

file word, pdf. Semua fasilitas tersebut bisa menjadi alternatif bagi guru untuk menyiapkan pembelajaran tanpa tatap muka. 


\section{Daftar Pustaka}

ADAGIDELİ, Fahretdin Hasan, Seda SARAÇ, and Engin ADER. "Assessing Preschool Teachers' Practices to Promote Self-Regulated Learning." International Electronic Journal of Elementary Education 7, no. 3 (2015).

Al-Attas, Syed Muhammad Naquib. 1979. Aims and Objectives of Islamic Education. Jeddah: King Abdul Aziz.

Al-Ghazali. 2008. Mutiara Ihya Ulumudin. Bandung: Mizan.

Biesenbach-Lucas, Sigrun. 2003. "Asynchronous discussion groups in teacher training classes: Perceptions of native and non-native students." Journal of Asynchronous Learning Network 7, no. 3 : 24-46.

Davis, Charles H.F., Regina Deil-Amen, Cecilia Rios-Aguilar, and Manuel Sacramento Gonzalez Canche. 2012. Social Media in Higher Education: A literature review and research directions. The Center for the Study of Higher Education at The University of Arizona and Claremont Graduate University.

Dialektika. Zoom Capai 131 Juta Download, Ini 10 Aplikasi Paling Banyak Diunduh Selama April. May 11, 2020. https://teknologi.id/aplikasi/zoom-capai-131-jutadownload-ini-10-aplikasi-paling-banyak-diunduh-selama-april.

Dianna R. Dekelaita Mullet, Kristen Lamb, Amy Willerson, Todd Kettler. 2016. "Examining teacher perceptions of creativity: A systematic review of the literature." Thinking Skills and Creativity 21: 9-30.

Friedman, Linda Weiser, and Hershey H. Friedman. 2013. "Using Social Media Technologies to Enhance Online Learning." Journal of education online 10, no. 1 .

Garrison, Donn Randy. 2017. E-learning in the 21 st century: A framework for research and practice. New York: Routledge,.

Hague, Sarah Payton and Cassie. 2010. Digital Literacy across the Curriculum. Bristol: Futurelab.

Hill, Janette R., and Michael J. Hannafin. 2001. "Teaching and learning in digital environments: The resurgence of resource-based learning." Educational Technology Research and Development 49, no. 3: 37-52.

Hootsuite ; We are Social. 2019. 10 Media Sosial yang Paling Sering Digunakan di Indonesia. Hootsuite (We are Social).

Jaschik, Scott. 2009. "The evidence on online education." Inside Higher Education, Juni 29.

Kementerian Kesehatan. 2020. Surat Edaran Nomor HK.02.01/Menkes/199/2020 Tentang Komunikasi Penanganan Covid-19. Jakarta: Menkes,. 
Langgulung, Hasan. 1995. Beberapa Pemikiran tentang Pendidikan Islam. Bandung: al-Ma'arif.

Lee, Ju-Sung, and Seok-Ju Chun. 2019. "Using Learning Management Systems for Self-directed Learning of Elementary School Students." Journal of The Korean Association of Information Education 23, no. 2 : 1229-3245.

Lee, Kyunghwa. 2017. What should be the innovative teaching and learning methods for future talent? International Future Society \& KERIS (Korea Education \& Research Information Service (Eds.). Paju: Kwnagmoongak.

LPM Idea. [In Depth] Kuliah Online Mahasiswa Korban Corona. April 28, 2020. https://www.ideapers.com/2020/04/in-depth-kuliah-online-mahasiswa-korbancorona.html.

Marzano, Robert J. 1986. An Evaluation of the Mc Rel Thinking Skills Program. Colorado: Mid-continent Regional Educational Laboratory,.

Menteri Pendidikan dan Kebuayaan. 2020. Surat Edaran Nomor 3 Tahun 2020 Tentang Pencegahan COVID-19 Pada Satuan Pendidikan. Jakarta: Mendikbud.

Muhaimin. 2015. "Model Kurikulum dan Pembelajaran dalam Pendidikan Islam Kontemporer." 51. Malang: UIN Maliki Press.

Perwitasari, Nur Hidayah. 2020. "Update Corona 8 Maret: 59.965 Orang Sembuh dari COVID-19." tirto.id, 38.

Petrides, Lisa. 2002. "Web-based technologies for distributed (or distance) learning: Creating learning-centered educational experiences in the higher education classroom." International Journal of Instructional Media 29, no. 1 : 69-77.

Rahman, Fazlur. 2005. " Islam dan Modernitas: tentang Transformasi Intelektual." By A. Mohammad, 102. Bandung: Pustaka.

Redaktur CNN Indonesia. 2020. "Jokowi Umumkan Dua WNI Positif Corona di Indonesia." CNN Indonesia, Maret 2.

Redaktur Kompas. 2020. "DATA COVID-19 DI INDONESIA." Kompas, 331.

Riadi, Yuni. Karena Covid-19, Google Classroom Sudah Diunduh 50 Juta. Maret 30, 2020. https://selular.id/2020/03/karena-covid-19-google-classroom-sudahdiunduh-50-juta/.

Song, Liyan, and Janette R. Hill. 2007. "A conceptual model for understanding selfdirected learning in online environments." Journal of Interactive Online Learning 6, no. $1: 27-42$.

Sulaiman, Fathiyah Hasan. 1990. Konsep Pendidikam Al Ghazali. Jakarta: Perhimpunan Pengembangan Pesantren dan Masyarakat (P3M). 
Misbahul Munir \& Triyo Suprayitno, Media Daring sebagai Self Directed Learning

Syed Muhammad Al-Naquib al-Attas, 1979. Aims and Objectives of Islamic Education (Jeddah: King Abdul Aziz.

Zainuddin. 1991. Seluk Beluk Pendidikan dari Al-Ghazali. Jakarta: Bumi Aksara. 